\title{
Human and canine blastomycosis: A common source infection
}

\author{
MATTHEW W MORGAN MD, IRVING E SALIT MD
}

\begin{abstract}
MW MORGAN, IE SALIT. Human and canine blastomycosis: A common source infection. Can J Infect Dis 1996;7(2):147-151. In fall 1993 a man and a dog developed blastomycosis after visiting an island off Bayfield Inlet, Georgian Bay, located near Parry Sound, Ontario. The man recovered but the dog died of blastomycosis. It was hypothesized that the common source of exposure was the island since the permanent residences of the two cases were in different cities. One further case of human infection, based on positive serology, and four additional cases of probable canine blastomycosis were identified. All cases had travelled to Bayfield Inlet during summer and early fall 1993. To the authors' knowledge this is the first Canadian report of a common source of infection of human and canine blastomycosis. This report also provides evidence for a new endemic area of blastomycosis infection.
\end{abstract}

Key Words: Blastomycosis

\section{Blastomycose humaine et canine : source commune de l'infection}

RÉSUMÉ : À l'automne de 1993, un homme et un chien ont développé une blastomycose après avoir visité une île au large de l'anse Bayfield dans la baie Georgienne, située près de Parry Sound, en Ontario. L'homme a récupéré, mais le chien est décédé de blastomycose. Selon une hypothèse, la source commune de l'exposition a été l'île, puisque les résidences permanentes de deux cas étaient situées dans des villes différentes. Un autre cas d'infection chez l'humain sur la base d'une sérologie positive et quatre autres cas de blastomycose canine probable ont été identifiés. Tous les cas s'étaient rendus à l'Anse Bayfield durant l'été et le début de l'automne 1993. Selon l'auteur, il s'agit du premier rapport canadien faisant état d'une source commune de blastomycose chez l'homme et le chien. Ce rapport confirme également l'existence d'une nouvelle région endémique de blastomycose.

$\mathrm{N}$ orth American blastomycosis is a fungal infection caused by Blastomyces dermatitidis. It is often a systemic illness involving lung, skin and bone. In North America blastomycosis is endemic in areas adjoining some of the major rivers and the Great Lakes. Important epidemiological information has been derived from outbreaks of blastomycosis, which have often involved recreational activities in wooded areas along waterways. Furthermore, ever since the illness was first described, it was known that dogs were susceptible to the infection. We describe a small outbreak of blastomycosis that involved dogs and humans who had visited an island in Georgian Bay, Ontario.

The Toronto Hospital, University of Toronto, Toronto, Ontario

Correspondence and reprints: Dr Irving E Salit, The Toronto Hospital, General Division, 200 Elizabeth Street, Eaton North G-216, Toronto, Ontario M5G 2C4. Telephone 416-340-3697, fax 416-348-8702, e-mail irving.salit@utoronto.ca

Received for publication September 13, 1995. Accepted January 23, 1996 


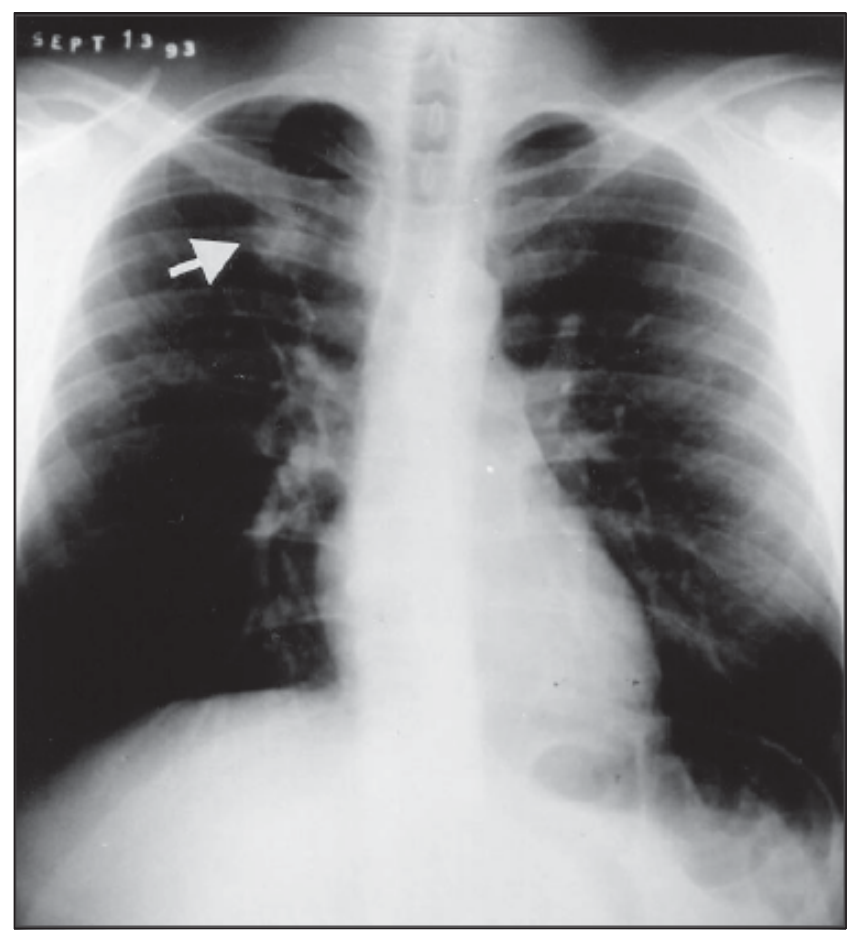

Figure 1) Human blastomycotic nodule. Chest x-ray of index case 1 showing a right upper lobe nodule

\section{CASE PRESENTATION}

Index case one: A 44-year-old Caucasian male presented in October 1993 with an asymptomatic right upper lobe nodule detected by routine chest radiograph (Figure 1). There was a past medical history of malignant melanoma of the back diagnosed in 1979 with recurrence to the right groin in 1984. Both were treated with wide surgical resection. The patient had been disease-free since 1984. A chest radiograph in October 1992 was unremarkable. The patient was a physically fit nonsmoker with no significant family or occupational history.

The patient lived in Toronto and travelled each summer to a small privately owned island off Bayfield Inlet in Georgian Bay, Ontario, located near Parry Sound and approximately $275 \mathrm{~km}$ north of Toronto. The island was inhabited by numerous animals including a brown bear, raccoons and beavers. The terrain included a marshy pond and several man-made dwellings. There had been no recent excavations.

Further investigations of the pulmonary nodule included routine blood work, bronchoscopy, computed tomography of the chest, abdominal ultrasound and fine needle biopsy. These investigations did not reveal evidence of metastatic melanoma or primary lung carcinoma.

The patient underwent open lung biopsy in November 1993. A well-defined lesion measuring $1 \times 1.5 \mathrm{~cm}$ and a right bronchial lymph node were excised from the right upper lobe. There was no mediastinal lymphadenopathy. The nodule and lymph node revealed a nonnecrotizing granulomatous reaction with budding yeast cells characteristic of Blastomyces dermatitidis (Figure 2).

The patient's postoperative course was uncomplicated.

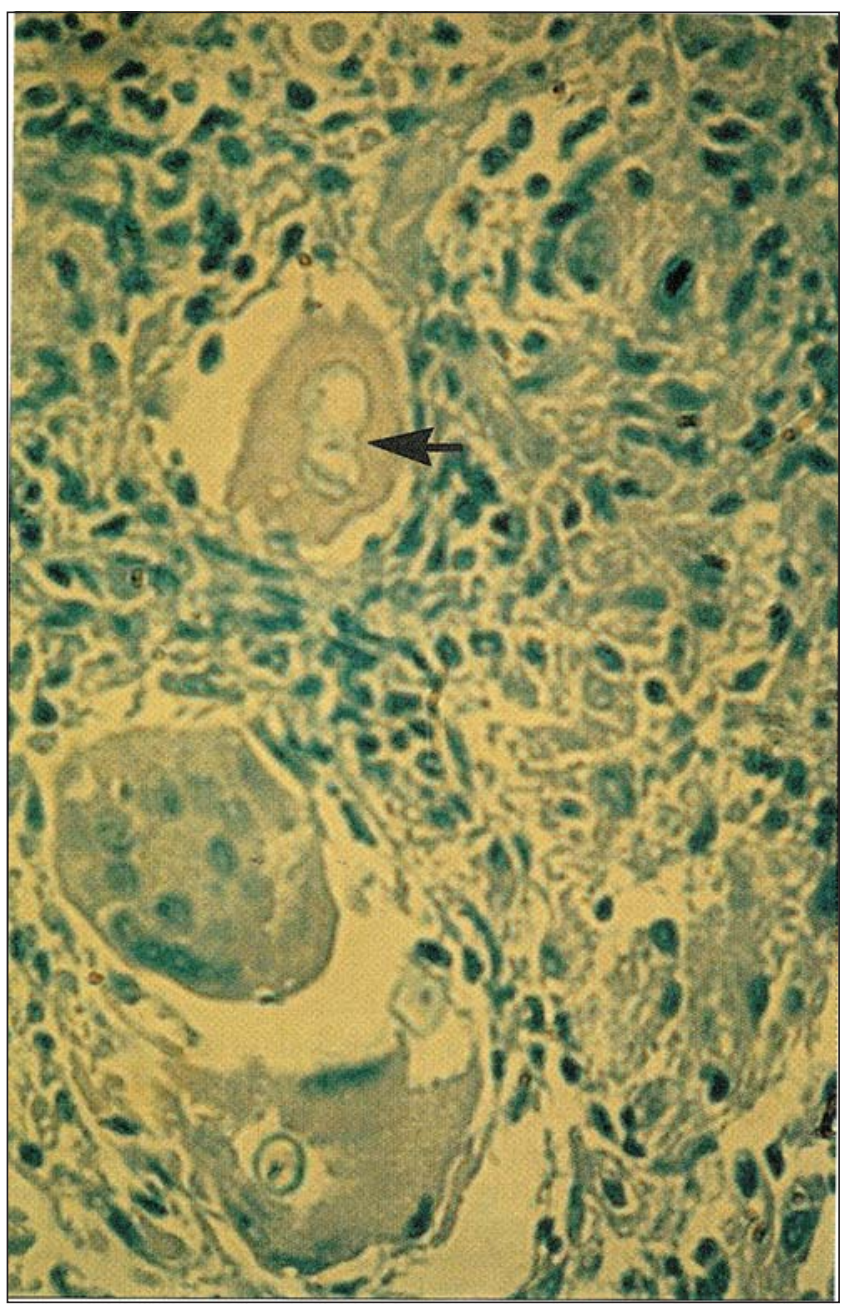

Figure 2) Index case 1, showing Blastomycoses dermatitidis stained with GMS. Pulmonary nodule $x 432$

Treatment with itraconazole $200 \mathrm{mg} /$ day was initiated because of possible residual lymph node involvement. The patient completed three months of itraconazole therapy without complications. There was no clinical evidence of blastomycosis. Index case two: A previously well three-year-old male Dalmatian dog presented in October 1993 with worsening dyspnea. He was found to have severe pneumonia (Figure 3), generalized lymphadenopathy and several skin lesions. Aspiration of a lymph node and subcutaneous nodule revealed broad-based budding yeast consistent with B dermatitidis (Figure 4). Despite treatment with antifungal therapy the dog succumbed to the infection.

The dog lived in the town of Oakville, $300 \mathrm{~km}$ from the island in question. The dog's travel history was also positive for annual summer trips to the island visited by index case 1 . The two cases shared no other common geographical exposure. Close contact between the two cases was minimal and neither had been injured by the other.

The common-source exposure of the two index cases is hypothesized to be the island described. In an attempt to identify other possible cases, an assessment was conducted of several individuals who visited the island during summer 1993. Eight 


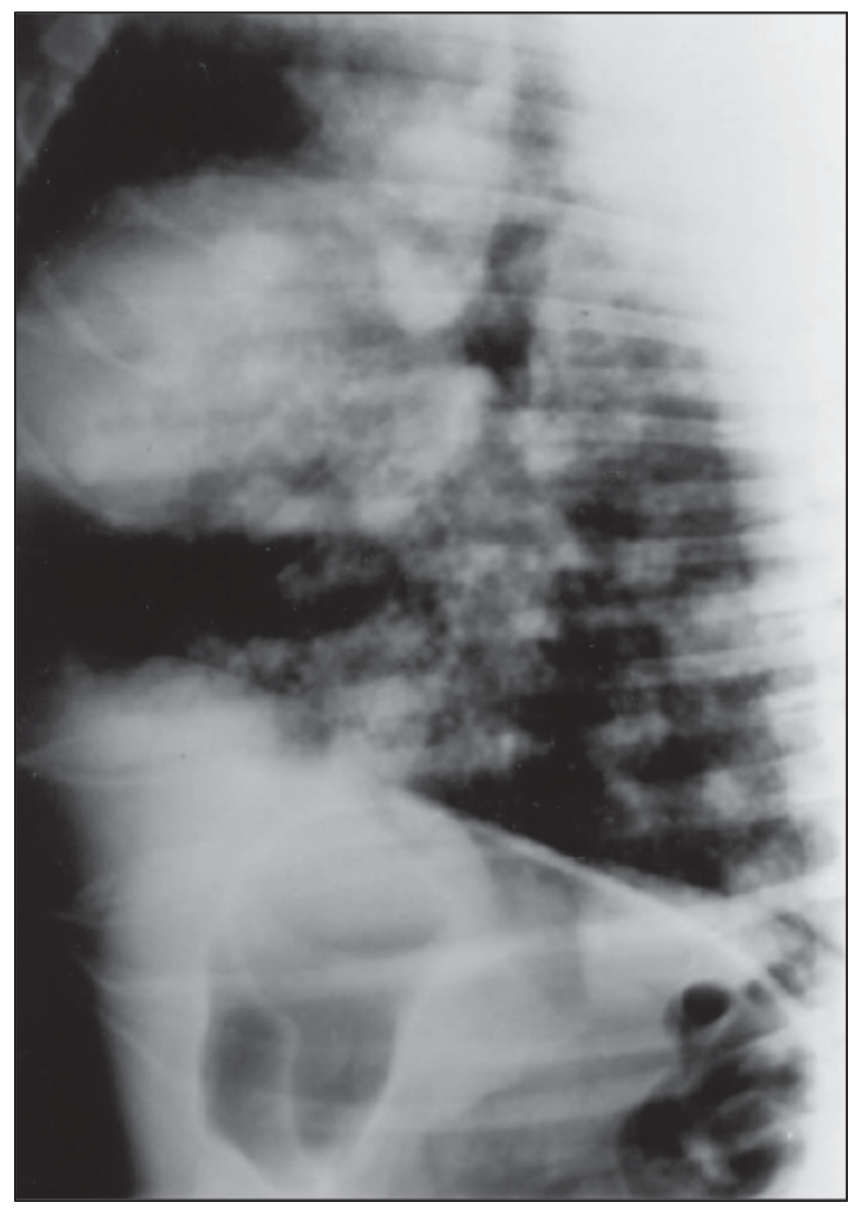

Figure 3) Canine blastomycosis. Chest x-ray of index case 2 showing diffuse pulmonary infiltrates

additional subjects underwent clinical evaluation and serological testing (complement fixation and enzyme immunoassay) to determine the presence of infection with B dermatitidis. Informed consent was obtained from all human subjects or their parents or guardians who participated in this study. Guidelines for human experimentation were followed in the conduct of this clinical research. All results were negative, except for a positive enzyme immunoassay in the 11-year-old son of index case 1. He was asymptomatic.

An informal survey of veterinarians from the adjacent Parry Sound region revealed four further cases of suspected canine blastomycosis. All four dogs had travelled to Bayfield Inlet during summer and early fall 1993 . They presented with pneumonia and all four dogs died from the disease. In two of the four cases microscopic examination for B dermatitidis was undertaken and confirmed the diagnosis. Retrospective diagnoses of the other two cases were based on clinical findings only.

\section{DISCUSSION}

North American blastomycosis is caused by the dimorphic fungus $B$ dermatitidis. The primary route of infection is by inhalation of the mycelial form. The fungus converts to the yeast

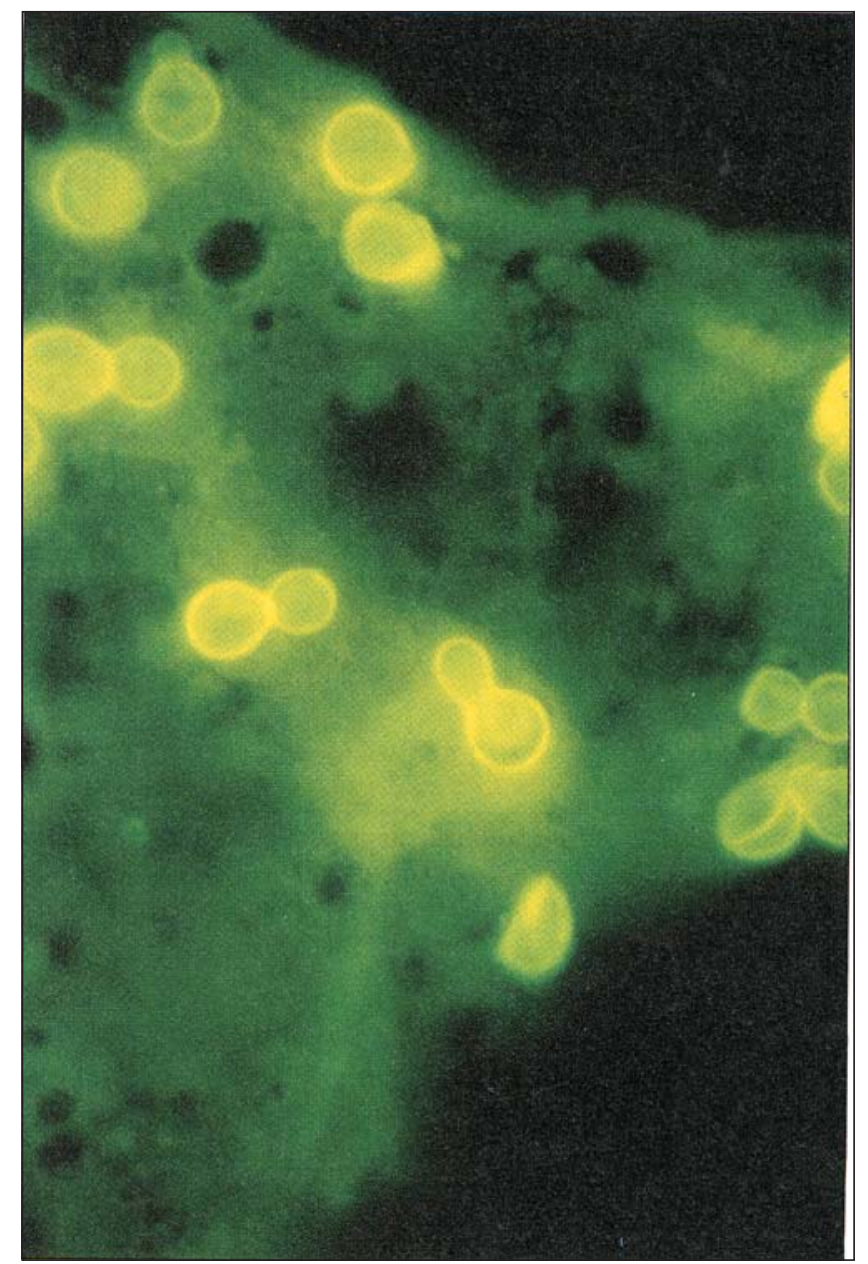

Figure 4) Index case 2, showing Blastomycoses dermatitidis stained with Fungi Fluor. Subcutaneous nodule $x 432$

form at body temperature (1). Self-limiting pulmonary infection with complete resolution appears to be the most common clinical manifestation; however, more extensive pulmonary involvement including pleural disease and adult respiratory distress syndrome as well as extrapulmonary dissemination to the skin, bones, prostate, meninges, adrenal glands, lymph nodes and spleen can occur (1-3).

There have been nine published outbreaks of blastomycosis (Table 1) (4-12). A common source exposure was suggested in six, two of which involved both humans and dogs $(9,12)$. Most outbreaks occurred in the summer and fall and were closely associated with contact with surface water. The most common presentation of culture-proven blastomycosis was asymptomatic pulmonary infection (57\% of cases); disease was usually self-limited. Only one of the 130 human cases of blastomycosis reported in these nine outbreaks died (4), whereas all nine dogs died $(9,12)$. There was no evidence of canine-human transmission of infection. The incubation period, when estimated, ranged from 21 to 106 days $(5,8,10,11)$. $B$ dermatitidis was successfully isolated from the environment in only two of the outbreaks $(9,11)$.

The endemic areas for B dermatitidis, based on the reported cases, occur in central, north-central and eastern United 
TABLE 1

Summary of nine outbreaks of blastomycosis: 1953-88

\begin{tabular}{|c|c|c|c|c|c|c|c|c|c|}
\hline Month/year & $\mathbf{N}$ & $\mathbf{M} / \mathbf{F}$ & Location & Diagnosis & Presentation & $\mathbf{R x}$ & Cured/total & Source & Ref \\
\hline $10 / 53-05 / 54$ & 11 & $6 / 5$ & Grifton, NC & C 11, CF 3/8 & Pulm (S) 11/11 & $8 / 11$ & $10 / 11$ & $?$ & 4 \\
\hline $11 / 72$ & 12 & $7 / 5$ & Bigfork, MN & C 4, CF 4 & Pulm (S) 7 & No & $12 / 12$ & Wood cabin & 5 \\
\hline $12 / 75-01 / 76$ & 5 & $1 / 4$ & Enfield, NC & C 5 & Pulm (S) 5 & $?$ & $5 / 5$ & ? & 6 \\
\hline $08 / 74-04 / 75$ & 5 & $3 / 2$ & Westmont, IL & C 5, CF 2 & $\begin{array}{l}\text { Pulm (S) } 4 \\
\text { Cut } 1\end{array}$ & 5 & $5 / 5$ & $?$ & 7 \\
\hline $07 / 79$ & 7 & $5 / 2$ & Hayward, WI & C 5, CF \& ID 0 & $\begin{array}{c}\text { Pulm (S) } 5 \\
\text { Pulm (AS) } 2\end{array}$ & No & $7 / 7$ & $\begin{array}{l}\text { Campsite } \\
\text { canoeing }\end{array}$ & 8 \\
\hline $03 / 84$ & 4 & $0 / 4$ & $\begin{array}{l}\text { Southampton, } \\
\text { VA }\end{array}$ & $\begin{array}{c}\text { C 3, CF 2, ID 3, } \\
\text { EIA } 4\end{array}$ & Pulm (S) 4 & 4 & $4 / 4$ & $\begin{array}{l}\text { Hunting } \\
\text { 4/4 dogs died }\end{array}$ & 9 \\
\hline $06 / 84$ & 48 & $16 / 32$ & Wisconsin & $\begin{array}{c}\text { C 9, CF 4, ID 13, } \\
\text { EIA } 37\end{array}$ & $\begin{array}{l}\text { Pulm (S) } 20 \\
\text { Pulm (AS) } 11\end{array}$ & 9 & $48 / 48$ & $\begin{array}{l}\text { Beaver lodge } \\
\text { Bd isolated }\end{array}$ & 10 \\
\hline 05-06/85 & 14 & $10 / 4$ & $\begin{array}{c}\text { Tomorrow \& } \\
\text { Crystal River, WI }\end{array}$ & $\begin{array}{l}\text { C } 11 / 14 \\
\text { EIA } 9 / 14\end{array}$ & $\begin{array}{l}\text { Pulm (S) } 13 \\
\text { Pulm (AS) } 1\end{array}$ & 13 & $14 / 14$ & $\begin{array}{l}\text { Fishing } \\
\text { timber fort } \\
\text { Bd isolated }\end{array}$ & 11 \\
\hline 06-11/88 & 22 & $10 / 12$ & $\begin{array}{l}\text { Watersmeet } \\
\text { Lake, WI }\end{array}$ & $\begin{array}{c}\text { C 3, CF \& ID 0, EIA } \\
18\end{array}$ & $\begin{array}{c}\text { Pulm (S) 3, Cut } \\
\text { 1, ASx } 16\end{array}$ & 3 & $22 / 22$ & $\begin{array}{l}\text { Excavation of hotel } \\
5 / 5 \text { dogs died }\end{array}$ & 12 \\
\hline
\end{tabular}

ASx Asymptomatic; Bd Blastomyces dermatitidis; C Positive culture; CF Positive complement fixation; Cut Cutaneous disease; ElA Positive enzyme immunoassay; ID Positive immunodiffusion; M/F Male/female; N Number of cases; Pulm (AS) Asymptomatic with abnormal chest x-ray; Pulm (S) Symptomatic pulmonary disease with abnormal chest x-ray; Rx Antifungal treatment

States with a propensity for the Ohio and Mississippi river basins and shores of Lake Michigan (13). In Canada, the vast majority of cases occur in Quebec, Ontario and Manitoba (14). In Ontario, the northeastern region of Lake Superior has been identified as an endemic area (15). 'North American blastomycosis' is a misnomer for there have been reported cases in other areas of the world, such as Africa (3).

Although blastomycosis is a relatively rare fungal disease in humans, in enzootic areas the incidence of canine disease is at least 10-fold higher. Compared with humans, dogs infected with B dermatitidis usually have a shorter incubation period, more extensive extrapulmonary dissemination and earlier progression of disease and death. Unlike that in humans, recovery from symptomatic infection in dogs is rare without treatment, most likely because of disseminated disease. Antifungal therapy in dogs is the same as in humans, with itraconazole being more effective than ketoconazole and equivalent in efficacy to amphotericin B. Fluconazole appears to be the least effective systemic antifungal (16). With early effective antifungal therapy, cure rates in dogs reach $80 \%$. The extent of pulmonary involvement has been shown to correlate with the likelihood of relapse and death (17).

The index cases described in this report likely represent a common source infection of human and canine blastomycosis. The source of exposure is believed to be the island in Georgian Bay. Evidence to support this hypothesis include the following: there was no other common source of exposure and the cases resided in separate permanent residences in different cities; there were documented additional cases of suspected canine blastomycosis from the same area during the same period; the incubation period was appropriate for blastomycosis; and there was no evidence of direct transmission. Although an attempt to culture B dermatitidis from the human index case was not successful, microscopic evaluation revealed strong evidence for B dermatitidis in both index cases. There was no attempt to culture B dermatitidis from the canine cases. Soil cultures from several parts of the island were negative for B dermatitidis. Serological testing of several human contacts who visited the island revealed one additional case of asymptomatic infection.

To our knowledge this is the first Canadian report of a common source infection of human and canine blastomycosis. The source of exposure, an island off Bayfield Inlet, Georgian Bay near Parry Sound, may represent a newly recognized endemic area of human blastomycosis infection in Ontario.

The clinician should be aware of endemic areas of blastomycosis when considering the differential diagnosis of pulmonary disease, especially in previously healthy individuals who are not responding to therapy. A detailed travel history and communication with a veterinarian from the area may provide important clinical clues to the diagnosis.

ACKNOWLEDGEMENTS: The authors thank Dr I Campbell for preparation of the histological slides, Dr N Gofton, Dr A Norris and Dr ACG Abrams-Ogg for their veterinary contribution and Ms Shirley Magnaye for her secretarial assistance.

\section{REFERENCES}

1. Bradsher RW. Blastomycosis. Clin Infect Dis 1992;14 (Suppl 1):S82-90.

2. Meyer KC, McManus EJ, Maki DG. Overwhelming pulmonary blastomycosis associated with the adult respiratory stress syndrome. N Engl J Med 1993;329:1231-6.

3. Sarosi GA, Davies SF. Blastomycosis. Am Rev Respir Dis 1979;120:911-38.

4. Smith JG Jr, Harris JS, Conant NF, Smith DT, Durham NC. An epidemic of North American blastomycosis. JAMA 1955;158:641-6. 
5. Tosh FE, Hammerman KJ, Weeks RJ, Sarosi GA. A common source epidemic of North American blastomycosis. Am Rev Respir Dis 1974;109:525-9.

6. Centers for Disease Control. Blastomycosis - North Carolina MMWR 1976;25:205.

7. Kitchen MS, Reiber CD, Eastin GB. An urban epidemic of North American blastomycosis. Am Rev Respir Dis 1977;115:1063-6.

8. Cockerill FR III, Roberts GD, Rosenblatt JE, Utz JP, Utz DC. Epidemic of pulmonary blastomycosis (Namekagon Fever) in Wisconsin canoeists. Chest 1984;86:688-92.

9. Armstrong CW, Jenkins SR, Kaufman L, Kerkering TM, Rouse BS, Miller GB Jr. Common-source outbreak of blastomycosis in hunters and their dogs. J Infect Dis 1987;155:568-70.

10. Klein BS, Vergeront JM, Weeks RJ, et al, and the Investigation Team. Isolation of Blastomyces dermatitidis in soil associated with a large outbreak of blastomycosis in Wisconsin. $\mathrm{N} \mathrm{Engl} \mathrm{J}$ Med 1986;314:529-34.

11. Klein BS, Vergeront JM, DiSalvo AF, Kaufman L, Davis JP. Two outbreaks of blastomycosis along rivers in Wisconsin: isolation of Blastomyces dermatitidis from riverbank soil and evidence of its transmission along waterways. Am Rev Respir Dis 1987;136:1333-8.

12. Boumgardner DJ, Burdick JS. An outbreak of human and canine blastomycosis. Rev Infect Dis 1991;13:898-905.

13. Logsdon MT, Jones HE. North American blastomycosis: a review. Cutis $1979 ; 24: 524-34$.

14. Kepron MW, Schoemperlen CB, Hershfield ES, Zylak CJ, Cherniak RM. North American blastomycosis in central Canada: A review of 36 cases. Can Med Assoc J 1972;106:243-6.

15. Kane J, Righter J, Krajden S, Lester RS. Blastomycosis: a new endemic focus in Canada. Can Med Assoc J 1983;129:728-31.

16. Pappas PG, Bradsher RW, Chapman SW, et al. Treatment of blastomycosis with fluconazole: a pilot study. The National Institute of Allergy and Infectious Diseases Mycoses Study Group. Clin Infect Dis 1995;20:267-71.

17. Legendre AM. Blastomycosis. In: Greene CF, ed. Infectious Diseases of the Dog and Cat. Philadelphia: WB Saunders Co, 1980:669-78. 


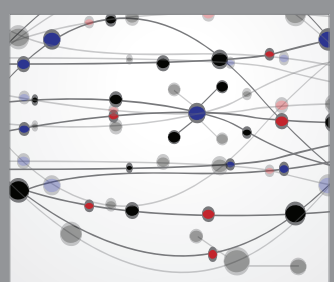

The Scientific World Journal
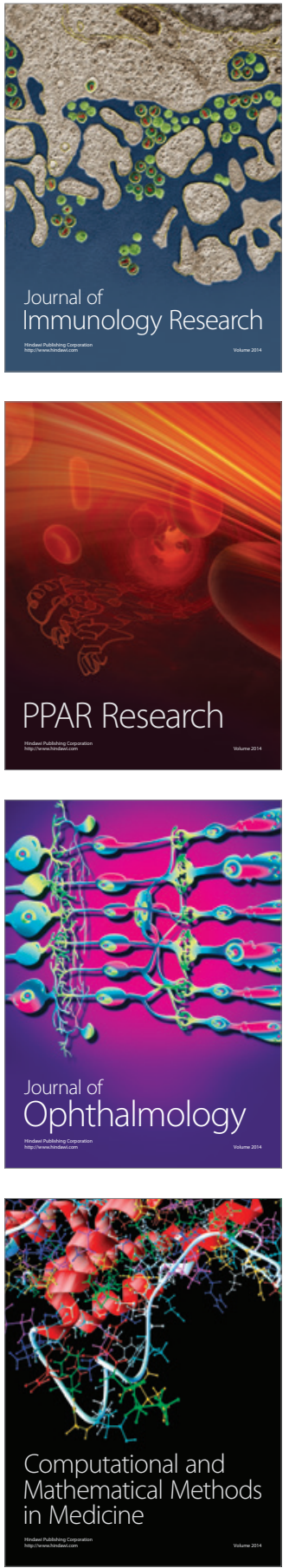

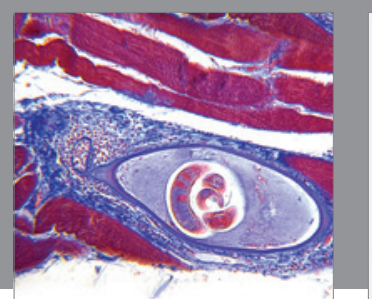

Gastroenterology Research and Practice

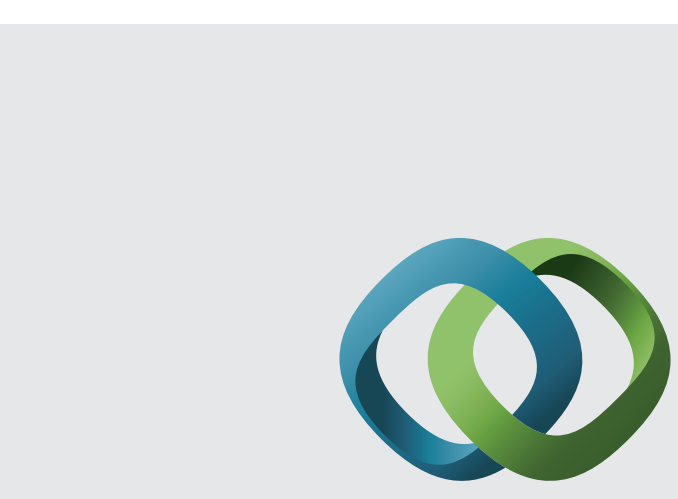

\section{Hindawi}

Submit your manuscripts at

http://www.hindawi.com
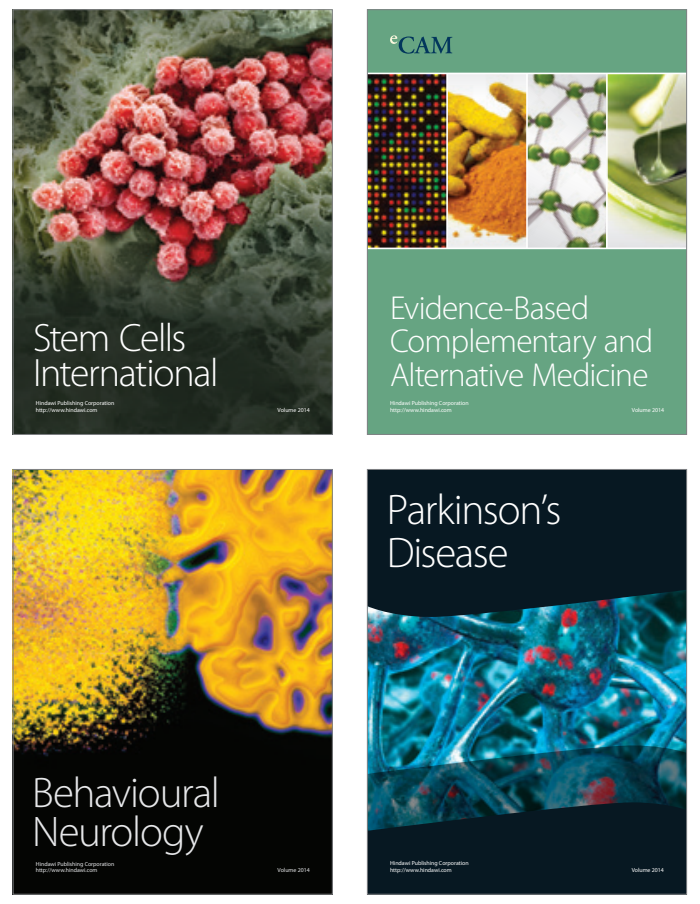
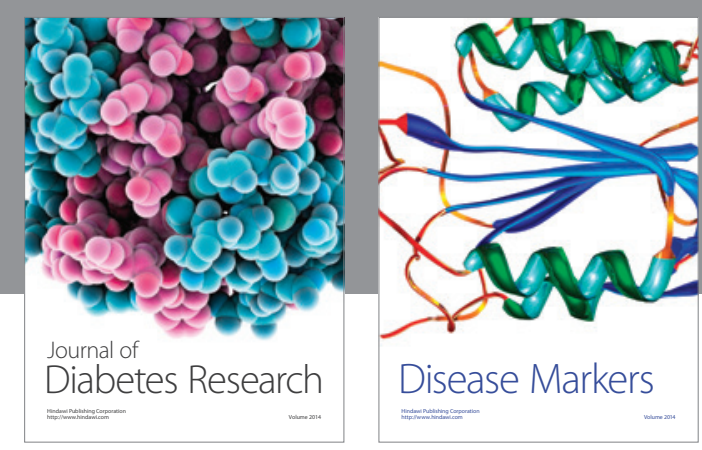

Disease Markers
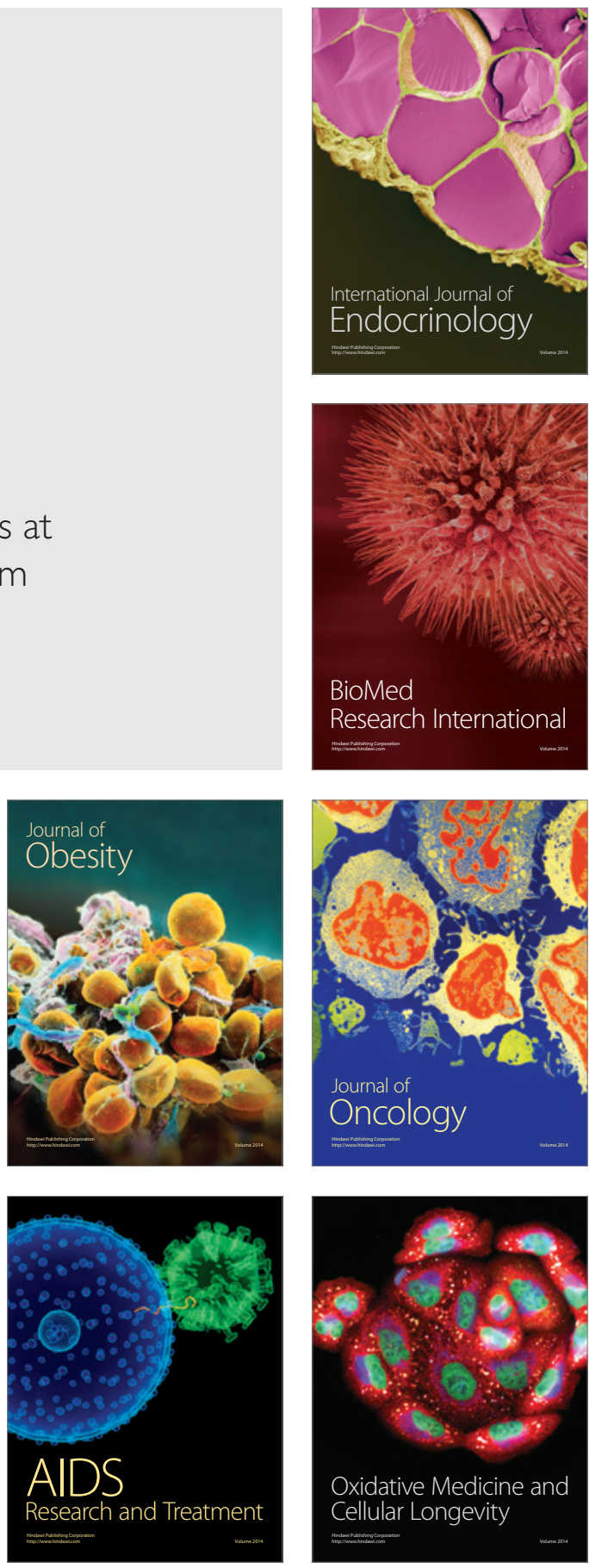